\title{
IMPACT OF LIVESTOCK GRAZING ON PLANT AND SMALL MAMMAL COMMUNITIES IN THE RUBY MOUNTAINS, NORTHEASTERN NEVADA
}

\author{
Eric A. Rickart ${ }^{1}$, Klaus G. Bienek ${ }^{2}$, and Rebecca J. Rowe ${ }^{3}$
}

\begin{abstract}
AвsтRACT.-We assessed the effects of livestock grazing on vegetation and small mammals in semiarid habitat at a site in northeastern Nevada. Habitat within a fenced exclosure that had been protected from grazing for more than 50 years supported more vegetation and had greater plant diversity compared to habitat immediately outside the exclosure. Likewise, species richness and abundance of small mammals were greater in ungrazed areas. Results suggest that grazing regulation in recent decades may account for some of the changes seen in regional plants and small mammals over the past century. The incorporation of long-term exclosures in a comparative framework permits differentiation of the direct effects of grazing on biotic communities and thus provides a reference point for assessing the influence of grazing relative to other factors in the interpretation of historical change.
\end{abstract}

RESUMEN.-Se evaluaron los efectos del pastoreo sobre la vegetación y pequeños mamíferos en habítat semiárido en un sitio en Nevada del noreste. Hábitat dentro de un cercamiento que habían sido protegido de pastoreo para más de 50 años tenía más vegetación y había una mayor diversidad de plantas en comparación con el hábitat inmediatamente fuera el cercamiento. Además, la riqueza de especies y abundancia de mamíferos pequeños fueron mayores en áreas protegidas. Los resultados sugieren que la regulación del pastoreo en las últimas décadas puede explicar algunos de los cambios observados en plantas y pequeños mamíferos de la región durante el siglo pasado. La incorporación de cercamientos de largo duración en un marco comparativo permite la diferenciación de los efectos directos del pastoreo sobre comunidades bióticas, y por lo tanto ofrece un punto de referencia para evaluar la influencia del pastoreo en relación con otros factores al interpretar el cambio histórico.

By virtue of its size and geographic complexity, the Great Basin of western North America supports a wealth of biological diversity. The present-day biotic communities of this region have been shaped by episodic shifts in climate that occurred throughout the Quaternary (Grayson 2011). This rich natural legacy is now threatened by accelerating rates of climate change driven by anthropogenic activities (Meehl et al. 2007). Since the mid 20th century, the Great Basin ecoregion has experienced increased temperature and precipitation, declining winter snowpack, and earlier arrival of spring - trends that are projected to intensify over the next century (reviewed by Chambers 2008). In addition, this region has been subject to a variety of transformative land uses over the past 150 years (Chambers and Wisdom 2009). Collectively, land uses have led to altered vegetation structure, diversion of water, introduction of invasive plants, and increased frequency of fire, all factors that have directly or indirectly altered natural plant and animal communities (Miller and Wigand 1994, Knapp 1996). As a result, the Great Basin is now considered one of the most severely threatened ecosystems of North America (Noss et al. 1995).

Climate and land use may interact to influence biotic communities in a complex manner. As such, it is necessary to distinguish separate effects of both to better understand or predict biotic responses and potentially mediate future impacts (Foster et al. 2003, Pyke and Marty 2005, Rowe 2007). Because all biotic change occurs within a historical context (Swetnam et al. 1999, Carpenter 2002), any knowledge of previous conditions is extremely valuable both in assessing the magnitude and direction of current changes and in teasing apart effects of land-use history from those of shifting climate.

This perspective is central to the approach used in biotic resurveys, where historical data

\footnotetext{
${ }^{1}$ Natural History Museum of Utah, University of Utah, 301 Wakara Way, Salt Lake City, UT 84108. E-mail: rickart@nhmu.utah.edu

${ }^{2}$ West Jordan High School, 8136 South 2700 West, West Jordan, UT 84088.

${ }^{3}$ Department of Natural Resources and the Environment, University of New Hampshire, 56 College Road, Durham, NH 03824.
} 
provide a comparative baseline for understanding current conditions and for determining probable future directions of change (e.g., Parmesan et al. 1999, Rooney et al. 2004, MillerRushing and Primack 2008, Moritz et al. 2008, Tingley et al. 2009, Rowe et al. 2011). Modern-day comparisons across land-use treatments can provide critical insights into the effects of management, both past and present, on native habitat and on the diversity and distribution of wildlife.

Recent resurveys in the Ruby Mountains of northeastern Nevada have documented changes in community structure of small mammals across an 80-year interval (Rowe et al. 2010, 2011). Some of these are associated with significant changes in vegetation, as documented through comparison between current conditions and written accounts and photographs from the 1920s (Borell and Ellis 1934, Rowe et al. 2010). Vegetation changes include the spread of piñonjuniper woodland, the expansion of shrublands into former grasslands, and the invasion and establishment of nonnative plants. Because these changes have occurred within the context of both regional climate change and changes in human land use, it is important to assess the relative impact of these different causal factors.

In the western United States, production of domestic livestock is one of the oldest and most widespread land-use practices (Fleischner 1994, Vavra et al. 1994). Public lands that are grazed by free-ranging livestock often include fenced areas where livestock have been excluded (Sarr 2002). In the absence of longterm, large-scale manipulations, preexisting livestock exclosures provide unique opportunities to directly assess the local impact of grazing on plant and small mammal assemblages in a context naturally representative of the landuse history of the region.

Here, we report results of paired surveys of plants and small mammals conducted within and outside a single long-term ( $~ 50$-year) livestock exclosure in semiarid shrubland in the Ruby Mountains. Our comparisons focus on species richness and community composition, with an emphasis on species-specific changes by functional group. Our aim is to obtain basic information on the local impact of grazing that can serve as a basis for interpreting how historical trends in livestock grazing have affected modern-day plant and animal communities throughout this region.

\section{Methods \\ Study Area}

The Ruby Valley Forest Service Station $\left(40.7320^{\circ} \mathrm{N}, 115.2290^{\circ} \mathrm{W}, \mathrm{NAD} 1927,2000 \mathrm{~m}\right.$ elevation) is located along the channel of Ruby City Creek at the boundary of the HumboltToiyabe National Forest on the eastern slope of the Ruby Mountains in Elko County, Nevada (Fig. 1). The station, which was established in the 1930s, includes several hectares of fenced ground. The oldest fenced areas originally served as pasture for horses and mules. With diminished use of saddle and pack animals by the Forest Service, these areas were transformed and expanded into a fenced livestock exclosure. Detailed information on this transition was not available, but livestock were excluded from this area for at least 50 years prior to our study (G. Brown, USDA Forest Service, personal communication, 2008). The exclosure was constructed with post and barbed wire fencing that is effective for excluding cattle but does not interfere with movements of small mammals. This design does not exclude mule deer, the most common native ungulate in the Ruby Mountains.

Plant assemblages within and surrounding the station included mixed shrub and woodland dominated by big sagebrush (Artemisia tridentata), antelope bitterbrush (Purshia tridentata), Utah serviceberry (Amelanchier utahensis), rubber rabbitbrush (Ericameria nauseosa), Woods' rose (Rosa woodsii), quaking aspen (Populus tremuloides), and curl-leaf mountain mahogany (Cercocarpus ledifolius). Water availability was comparable within and immediately outside the exclosure. Several small springs and seeps were present east of the station both within and outside the exclosure. The natural channel of Ruby City Creek on the southern boundary of the exclosure (Fig. 1) was completely dry and supported no riparian vegetation. The creek had been diverted from the natural channel several years prior to our study. The nearest flowing water available for livestock was an unnamed stream $\sim 0.5 \mathrm{~km}$ north of the station that supported riparian vegetation dominated by willow (Salix sp.) and Woods' rose. The grazing allotment that includes the Ruby Valley station encompasses an area of more than $20 \mathrm{~km}^{2}$ (USDA-FS 2013). In the years preceding our study, this allotment was grazed by cattle on a 3-year cycle. This cycle 


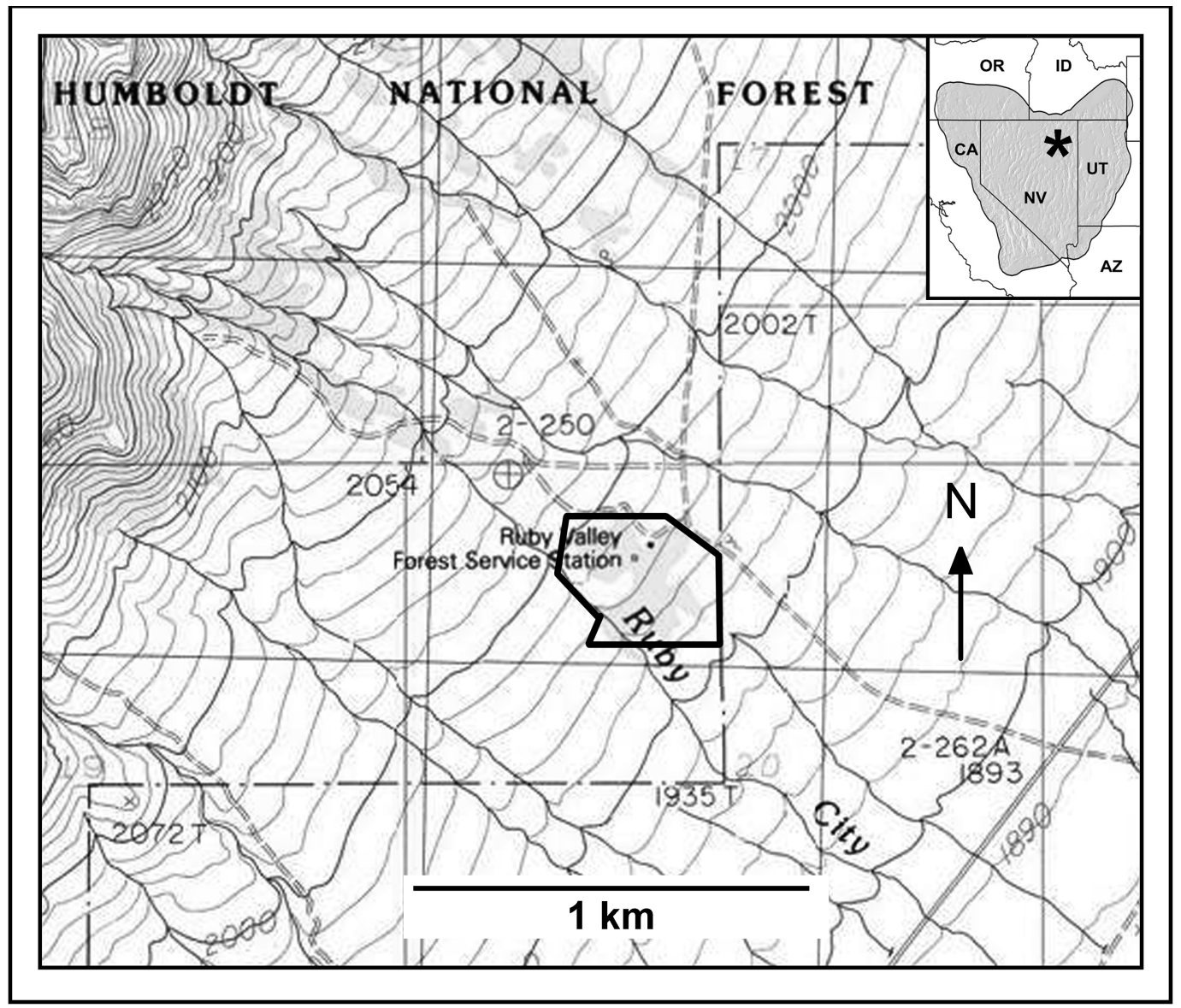

Fig. 1. Ruby Valley Forest Service Station, Elko County, Nevada. Polygon shows the boundaries of the long-term grazing exclosure.

involved limited grazing during spring and summer of 2 consecutive years, followed by a third year with no livestock. During 2006, the allotment was not grazed. In 2007, it supported 250 cow-calf pairs between 15 July and 26 August (42 d). In 2008, 250 cow-calf pairs grazed for a 45 -d period (1 June-15 July), after which the allotment entered a scheduled rest cycle that would continue through the following year (G. Brown, USDA Forest Service, personal communication, 2008). As such, with the exception of ungrazed areas within the exclosure, the allotment had received its maximum scheduled use immediately prior to our surveys at the Ruby Valley station in late July 2008.

Field Methods

We conducted paired surveys of vegetation and small mammals in grazed habitat and in adjacent protected habitat within the livestock exclosure that remained ungrazed prior to and during the study. The exclosure encompassed an area of $\sim 10$ ha and supported mixed shrubs and aspen, with more mesic habitat at the eastern end where springs and seeps were located. Comparative surveys were conducted in an area of comparable size (8-10 ha) immediately to the north of the station exclosure. This area was freely accessible to cattle when they were present (Fig. 1). The adjacent grazed and ungrazed sampling areas were similar with respect to water, slope, and soil type, differing only in their accessibility to livestock.

We measured ground cover and vegetation features in ungrazed and grazed habitat within and outside the grazing exclosure. For 10 randomly selected $1-\mathrm{m}^{2}$ plots in each area, we 
TABLE 1. Mean (SE) percent cover on $1-\mathrm{m}^{2}$ plots in grazed $(n=10)$ and protected $(n=10)$ habitat at Ruby Valley Forest Service Station, Nevada. Values greater than expected are shown in bold type.

\begin{tabular}{|c|c|c|c|c|}
\hline Cover type & Grazed & Ungrazed & $t$ & $P$ \\
\hline Grass/rush & $5.4(1.0)$ & $31.9(8.0)$ & 3.8807 & 0.004 \\
\hline Forbs & $6.2(2.2)$ & $9.9(2.5)$ & 1.1424 & 0.283 \\
\hline Woody plants & $38.3(6.9)$ & $9.8(3.3)$ & 3.9162 & 0.004 \\
\hline Open ground & $42.4(6.0)$ & $33.7(5.5)$ & 1.4031 & 0.194 \\
\hline Woody debris & $7.7(3.8)$ & $14.7(5.1)$ & 1.1773 & 0.269 \\
\hline
\end{tabular}

estimated percent ground cover for 5 standard categories: grass/rush, forbs, woody plants, coarse woody debris, and open ground. To assess plant species richness, we provisionally identified all plants present in individual sampling plots, and representative specimens were collected for later verification. Plant characteristics were used to define the following functional groups: native or nonnative, mesic or xeric habitat association, importance as livestock forage, and toxicity to livestock (Whitson et al. 1992, USDA-NRCS 2009). We measured woody plant density by using counts along line transects. In both grazed and ungrazed areas, we randomly selected 2 points, from which we ran 4 straight-line transects for $18 \mathrm{~m}$ in each cardinal compass direction. Along each transect, we counted the number of woody plants encountered within $0.5 \mathrm{~m}$ of either side of a central line, representing an area of $18 \mathrm{~m}^{2}$ per transect and a total of $144 \mathrm{~m}^{2}$ for both grazed and ungrazed habitat.

We assessed species richness and relative abundance of small mammals (rodents and shrews) by removal trapping, using Museum Special snap-traps. In each area, we established multiple discrete traplines (ranging from 45 to 100 traps) to sample small mammals across the full range of available microhabitats. Traps were baited with a mixture of peanut butter and oatmeal and set 3-5 m apart at locations of probable small mammal activity (e.g., near putative burrow openings, along runways, and under available cover). Traplines were run for either 3 or 4 nights from 20 to 24 July 2008. Trapping effort was expressed as the number of trap-nights (a trap-night defined as one trap set for $24 \mathrm{~h}$ ). Effort totaled 1225 trap-nights, including 620 within the exclosure and 605 outside. Comparisons were effort-standardized to account for this slight difference in effort. We assigned species to functional groups based on habitat affinity and diet (Rowe et al. 2011). Voucher specimens were prepared for all species and were deposited at the Natural History Museum of Utah. Small mammal trapping was done under permit from the Nevada Department of Wildlife. Methods followed guidelines of the American Society of Mammalogists (Gannon et al. 2007) and were approved by the Institutional Animal Care and Use Committee of the University of Utah (protocol \# 06-02001).

\section{Data analysis}

We used Student's $t$ tests to assess observed differences in cover type between grazed and ungrazed habitats. We used chi-square tests to assess effects of grazing on the relative abundance of small mammals and the woody plant species. In pairwise comparisons where sample size was less than 10, we used the binomial test. Expected frequencies of occurrence were calculated based on sampling effort and the null hypothesis of equal abundance in grazed and ungrazed areas. We used the Jaccard coefficient to measure similarity in plant assemblages in grazed and ungrazed habitats.

\section{RESUlts}

Sample plots in grazed and ungrazed areas revealed significant differences in overall assessment of ground cover (Table 1). Plots in ungrazed habitat had significantly more grass/ rush cover, whereas plots in the grazed area had more woody plant cover. Other cover categories did not differ significantly. Transect counts likewise showed a greater frequency of woody plants in the grazed area (Table 2), as well as significant heterogeneity in species composition of the plant assemblages on grazed and ungrazed habitat $\left(\chi^{2}=211.093\right.$, df $=7$, $P<0.0001)$.

Fifty-two plant taxa were identified from sampling plots and line transects, of which 30 were identified to species and 22 to genus (Appendix). Plant species richness in ungrazed habitat within the exclosure was nearly double 
TABLE 2. Counts of woody plants on line transects in grazed $(n=8)$ and ungrazed $(n=8)$ habitat at Ruby Valley Forest Service Station, Nevada.

\begin{tabular}{lcc}
\hline & \multicolumn{2}{c}{ Occurrence } \\
\cline { 2 - 3 } & Grazed & Ungrazed \\
\hline Amelanchier utahensis & 21 & 9 \\
Artemisia tridentata & 51 & 47 \\
Chrysothamnus viscidiflorus & 65 & 0 \\
Mahonia repens & 22 & 0 \\
Populus tremuloides & 0 & 53 \\
Purshia tridentata & 33 & 0 \\
Rosa woodsii & 51 & 0 \\
Symphoricarpos oreophilus & 0 & 2 \\
TOTAL INDIVIDUALS & 243 & 111 \\
\hline
\end{tabular}

TABLE 3. Representation of plant functional groups in grazed and ungrazed habitat at Ruby Valley Forest Service Station, Nevada.

\begin{tabular}{lrrrrr}
\hline & \multicolumn{2}{c}{ Grazed } & & \multicolumn{2}{c}{ Ungrazed } \\
\cline { 2 - 3 } Group & $n$ & & & $n$ & $\%$ \\
\hline Nonnative & 3 & 13.6 & & 3 & 7.1 \\
Mesic & 8 & 36.4 & & 21 & 50.0 \\
Xeric & 10 & 45.5 & & 17 & 40.5 \\
Forage & 10 & 45.5 & & 18 & 42.9 \\
Toxic & 3 & 13.6 & & 5 & 11.9 \\
ALL PLANTS & 22 & & & 42 & \\
& & & & &
\end{tabular}

TABLE 4. Abundance and attributes of small mammals trapped in grazed and ungrazed habitats at Ruby Valley Forest Service Station, Nevada. Expected frequencies based on trap effort are in parentheses. Totals greater than expected are shown in bold type.

\begin{tabular}{|c|c|c|c|c|c|c|}
\hline & \multirow{2}{*}{$\begin{array}{c}\text { Habitat } \\
\text { association }^{\text {a }}\end{array}$} & \multirow{2}{*}{$\begin{array}{l}\text { Foraging } \\
\text { guild }^{\mathrm{b}}\end{array}$} & \multicolumn{2}{|c|}{ Number of individuals } & \multirow[b]{2}{*}{$\chi^{2}$} & \multirow[b]{2}{*}{$P$} \\
\hline & & & Grazed & Ungrazed & & \\
\hline Sorex preblei & $\mathrm{X}$ & I & 0 & 1 & & \\
\hline Sorex vagrans & M & I & 3 & 1 & & \\
\hline Perognathus parvus & $\mathrm{X}$ & G & $15(21.2)$ & $28(21.8)$ & 3.577 & 0.057 \\
\hline Peromyscus maniculatus & G & $\mathrm{O}$ & 9 & 9 & & \\
\hline Microtus longicaudus & M & $\mathrm{H}$ & 0 & 1 & & \\
\hline Zapus princeps & M & $\mathrm{O}$ & $3(6.4)$ & $10(6.6)$ & & $0.04^{\mathrm{c}}$ \\
\hline TOTAL TRAP-NIGHTS & & & 605 & 620 & & \\
\hline TOTAL INDIVIDUALS & & & $30(39.5)$ & $\mathbf{5 0}(40.5)$ & 4.513 & 0.034 \\
\hline SPECIES RICHNESS & & & 4 & 6 & & \\
\hline
\end{tabular}

$\mathrm{a}=$ xeric, $\mathrm{M}=$ mesic, $\mathrm{G}=$ generalist.

$\mathrm{b}_{\mathrm{I}}=$ insectivore, $\mathrm{G}=$ granivore, $\mathrm{H}=$ herbivore, $\mathrm{O}=$ omnivore.

cBinomial test.

that recorded in the grazed habitat (42 vs. 22 ), and the similarity of plant assemblages in the 2 areas was low $(J=0.23)$. Of the total number of taxa recorded, 30 were found only in ungrazed habitat, 10 were found only in the grazed area, and 12 occurred in both. Although larger numbers of plant taxa belonging to mesic, xeric, and forage functional groups were recorded in ungrazed habitat, proportional representation of the groups did not differ significantly between the areas (Table 3 ).

Small mammal trapping involved a total of 1225 trap-nights and yielded 80 captures representing 6 species (Table 4). Species richness was greater in ungrazed habitat than in grazed habitat (6 vs. 4 species), and the total number of captures was significantly greater in ungrazed habitat (Table 4). The Great Basin pocket mouse (Perognathus parvus), categorized as a xeric habitat associate, accounted for more than half of the total captures and was significantly more abundant in ungrazed habitat. The western jumping mouse (Zapus princeps), a mesic species, also was more abundant in the ungrazed area. The deer mouse (Peromyscus maniculatus), an ecological generalist, showed no significant differences in abundance between habitats. The vagrant shrew (Sorex vagrans) was captured both within and outside exclosures but in insufficient numbers to interpret statistically. There were only single captures of Preble's shrew (Sorex preblei) and long-tailed vole (Microtus longicaudus), both from ungrazed habitat inside exclosures.

\section{Discussion}

Published literature on the effects of grazing on arid and semiarid ecosystems is varied and often contradictory (Jones 2000). Lack of uniformity is not unexpected among studies conducted under a wide range of conditions including variable grazing intensities, differences in habitat, and the confounding effects 
of other influencing factors. Nevertheless, because livestock forage selectively and can remove large quantities of plant biomass, their impact is often substantial (Pieper 1968, Fleischner 1994, Rosenstock 1996, Valone and Sauter 2004). Our study revealed significant effects of long-term grazing at the Ruby Valley station. The decreased herbaceous vegetation and increased woody vegetation that we observed have been noted in other studies (Austin and Urness 1998, Jones et al. 2003, Castellano and Valone 2007). Although we found decreased species richness of plants in grazed habitat, results of other studies show varied effects of grazing on plant diversity (Fleischner 1994, Jones 2000). Grazing has been associated with habitat xerification (Fleischner 1994, Van Auken 2000) and with increases in both nonnative plants (Parker et al. 2006) and plants toxic to livestock (Ralphs 2002). Our results did not reveal any of these trends.

The reported effects of grazing on small mammals are likewise varied. However, our findings generally confirm previous studies associating grazing with decreased community (or total) abundance (Bock et al. 1984, Heske and Campbell 1991, Schulz and Leininger 1991, Mathis et al. 2006) and lower diversity (Medin and Clary 1989, Rosenstock 1996, Valone and Sauter 2004). Grazing has also been associated with substantial shifts in community composition (Jones 1999, Jones et al. 2003), in particular a transition from mesicadapted to xeric-adapted mammals, and with increased representation of ecological generalists (Bock et al. 1984, Hayward et al. 1997, Jones et al. 2003, Rowe 2007). Although relatively low species richness and abundance at this site limits our ability to test for this trend, we note that one xeric and one mesic species were significantly more common in ungrazed habitat.

Of the 6 species of small mammals documented in our study, Sorex preblei is very poorly known; the specimen from this study was the first record for the Ruby Mountains region (Rickart et al. 2011). The other 5 species are common in the Ruby Mountains, where they have broad elevational ranges (Rowe et al. 2010). The close proximity of the 2 areas accounts for the close similarity in the 2 assemblages. The fact that we documented a larger number of species of mammals (including a rare shrew) and greater overall abundance of individuals inside the enclosure likely reflects the increased cover and higher species richness of plants in the ungrazed habitat and underscores the importance of such areas as local refugia from surrounding disturbance.

In Nevada, where large-scale livestock ranching started in the second half of the 19th century, grazing on public lands was essentially unrestricted prior to 1936 and was not closely regulated until after 1950 (Young and Clements 2006). Throughout the Ruby Mountains region, livestock grazing was certainly more widespread and more intensive in the late 19th and early 20th centuries than it is currently. In the years leading up to our study, grazing has been closely regulated by the USDA Forest Service. Photographic comparisons reveal substantial changes in regional plant communities, some of which may be direct or indirect consequences of reduced livestock grazing (Fig. 2). The fact that comparable changes in vegetation have been documented throughout the Intermountain Region (e.g., Rogers 1982, Kay 2003) speaks to the widespread and long-term impact of historical overgrazing and other land uses. Our exclosure comparisons reveal significant differences in vegetation cover and in the species richness and abundance of plants and small mammals in response to livestock grazing.

From our grazing exclosure study, we would predict that modern-day small mammal communities may be more diverse and abundant than those present during historical periods of overgrazing. However, results from an 80-year resurvey comparison of small mammal communities across the Ruby Mountains region revealed the opposite trend: a reduction in abundance that was independent of elevation and habitat type, and changes in community structure that involve loss of ecological specialists and increased representation of generalist species (Rowe et al. 2011). Although this discrepancy may illustrate some challenges associated with scaling up from a local case study to a region-wide phenomenon, it also underscores the difficulty with assessing causality in a system where multiple and interactive forces have shaped the modern-day landscape. For example, few species of mammals in the Ruby Mountains have had up-slope shifts in elevational range over the past century (Rowe et al. 2010), which is the expected 


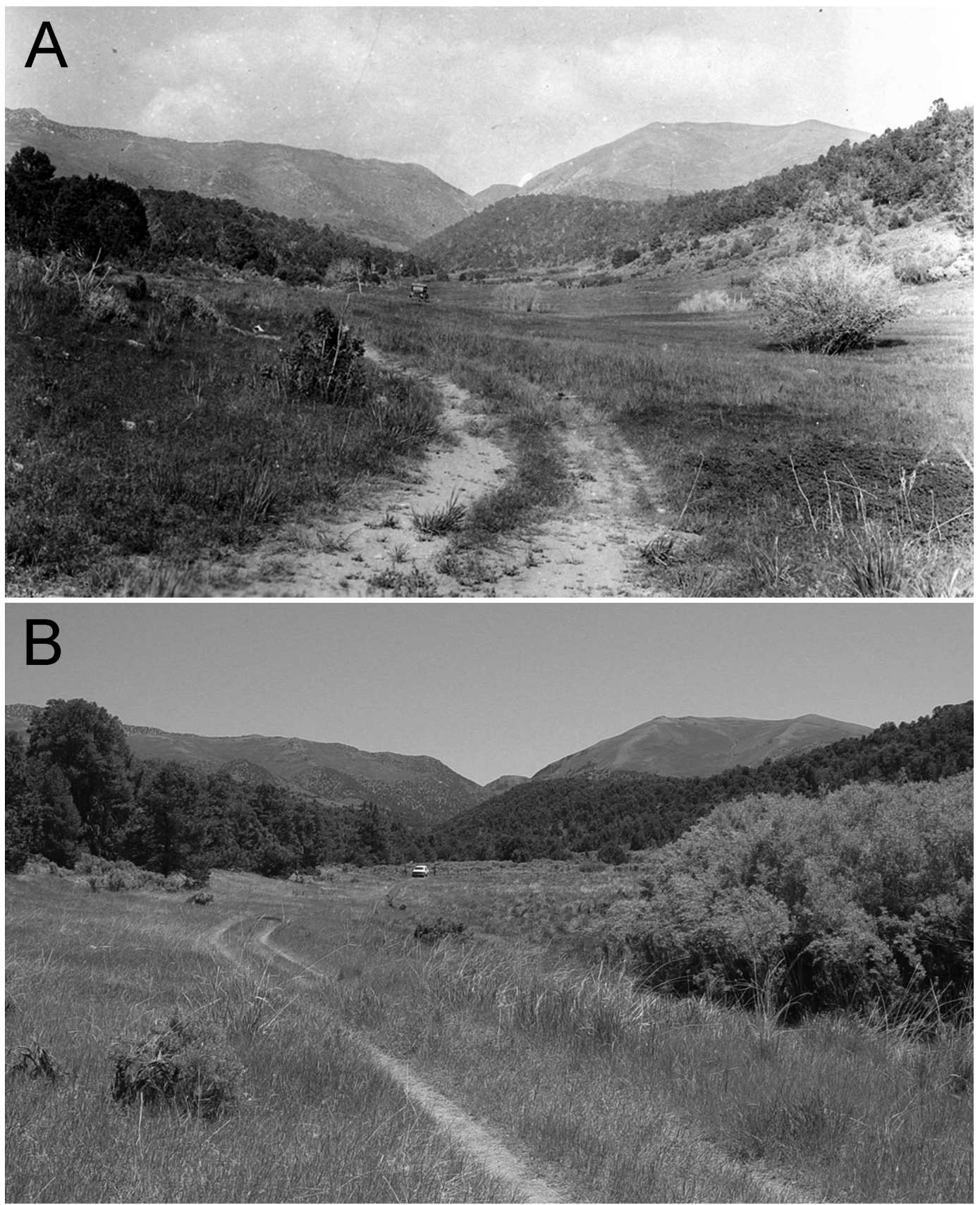

Fig. 2. Repeat photographs of Willow Creek Canyon (ca. 2000 m elevation), Ruby Mountains, White Pine Co., Nevada: A, photograph by A.E. Borell, late May or early June 1929 (courtesy of the Museum of Vertebrate Zoology, University of California); B, photograph by E.A. Rickart, 29 May 2007. Vegetation changes include increased density of herbaceous cover and willow in the meadow, and expansion of piñon-juniper woodland on surrounding slopes.

response to climate warming and a predominant pattern seen in the Sierra Nevada Range (Moritz et al. 2008). Notably, some species have had static elevational ranges or significant down-slope contractions or expansions (Rowe et al. 2010). In general, many of the 
temporal changes in the diversity and distribution of mammals in the Ruby Mountains do not appear to be direct responses to either reduced grazing or shifting climate; rather, these changes appear to be secondary responses to changes in vegetation. Major shifts in regional plant communities, including the expansion of piñon-juniper woodland into former shrubland (Miller et al. 2008) and the spread of cheatgrass (Knapp 1996), may restructure local small mammal communities (Gitzen et al. 2001, Rowe et al. 2010).

The biotic changes occurring in the Great Basin are complex, with multiple driving factors operating independently, in concert, or in opposition (Bradley 2010). The influence of these factors varies across spatial and temporal scales and may impact communities at different levels of organization. Many changes may also be mediated through complex, often novel, biotic interactions. This complexity remains a major challenge for future research, but it also represents an opportunity to investigate the ways in which management may impact wildlife and thus mitigate some of the anticipated effects of future climate change. Grazing exclosures and similarly protected areas constitute biological refugia that offer a means of directly assessing the long-term effects of historical land use. As such, they can provide much-needed benchmarks in efforts to determine the role of historical land use in effecting biotic change.

\section{ACKNOWLEDGMENTS}

We thank Lois Alexander, Debra Amundsen, Nels Anderson, Adam Biels, Carolyn Firestone, Mary Hall, Lorie Millward, Heather Paulsen, Anthony Ramirez, Eric Remington, Shannen Robson, and Duke Rogers for assistance with fieldwork, and Ann Kelsey for help with plant identifications. Terry Shute, Dave Ashby, and Gary Brown (USDA For est Service, Humboldt National Forest) provided advice, assistance, and information on local grazing history. We thank 2 anonymous reviewers for their constructive comments that helped improve the paper. This work was supported by the National Science Foundation (DEB 0919409), the National Geographic Society, the American Philosophical Society, and the University of Utah Research Foundation.

\section{Literature Cited}

Austin, D.D., AND P.J. Urness. 1998. Vegetal change on a northern Utah foothill range in the absence of livestock grazing between 1948 and 1982. Great Basin Naturalist 58:188-191.

Bock, C.E., J.H. Bock, W.R. Kenney, and V.M. HaWTHORNE. 1984. Responses of birds, rodents and vegetation to livestock exclosure in a semidesert grassland site. Journal of Range Management 37:239-242.

Borell, A.E., AND R. Ellis. 1934. Mammals of the Ruby Mountains region of northeastern Nevada. Journal of Mammalogy 15:12-44.

Bradley, B.A. 2010. Assessing ecosystem threats from global and regional change: hierarchical modeling of risk to sagebrush ecosystems from climate change, land use and invasive species in Nevada, USA. Ecography 33:198-208.

Carpenter, S.R. 2002. Ecological futures: building an ecology of the long now. Ecology 83:2069-2083.

Castellano, M.J., and T.J. Valone. 2007. Livestock, soil compaction and water infiltration rate: evaluating a potential desertification recovery mechanism. Journal of Arid Environments 71:97-108.

Chambers, J.C. 2008. Climate change and the Great Basin. Pages 29-32 in J. Chambers, N. Devoe, and A. Evenden, editors, Collaborative management and research in the Great Basin-examining the issues and developing a framework for action. General Technical Report RMRS-GTR-204, USDA Forest Service, Rocky Mountain Research Station, Fort Collins, CO.

Chambers, J.C., and M.J. Wisdom. 2009. Priority research and management issues for the imperiled Great Basin of the western United States. Restoration Ecology 17:707-714.

Foster, D., F. Swanson, J. Aber, I. Burke, N. Brokaw, D. Tilman, and A. Knapp. 2003. The importance of land legacies to ecology and conservation. BioScience 53:77-88.

FLeISCHNER, T.L. 1994. Ecological costs of livestock grazing in western North America. Conservation Biology 8:629-644.

Gannon, W.L., R.S. Sikes, and the Animal Care and Use Committee of the American Society of Mammalogists. 2007. Guidelines of the American Society of Mammalogists for the use of wild mammals in research. Journal of Mammalogy 88: 809-823.

Gitzen, R.A., S.D. West, and B.E. Trim. 2001. Additional information on the distributions of small mammals at the Hanford Site, Washington. Northwest Science 75:350-362.

Grayson, D.K. 2011. The Great Basin: a natural prehistory. University of California Press, Berkeley, CA.

Hayward, B., E.J. Heske, and C.W. Painter. 1997. Effects of livestock grazing on small mammals at a desert cienaga. Journal of Wildlife Management 61: 123-129.

Heske, E.J., and M. Campbell. 1991. Effects of an 11year livestock exclosure on rodent and ant numbers in the Chihuahuan Desert, southeastern Arizona. Southwestern Naturalist 36:89-93.

Jones, A. 2000. Effects of cattle grazing on North American arid ecosystems: a quantitative review. Western North American Naturalist 60:155-164. 
JonEs, A.L. 1999. Effects of cattle grazing on salt desert rodent communities. American Midland Naturalist 141:1-11.

Jones, Z.F., C.E. Bock, AND J.H. Bock. 2003. Rodent communities in a grazed and ungrazed Arizona grassland, and a model of habitat relationships among rodents in southwestern grass/shrublands. American Midland Naturalist 149:384-394.

KAY, C.E. 2003. Long-term vegetation change on Utah's Fishlake National Forest: a study in repeat photography. USDA Forest Service and Utah State University Extension, Logan, UT.

KNAPP, P.A. 1996. Cheatgrass (Bromus tectorum L) dominance in the Great Basin Desert: history, persistence, and influences to human activities. Global Environmental Change 6:37-52.

Mathis, V.L., W.G. Whitford, F.R. KaY, and P.U. AlKon. 2006. Effects of grazing and shrub removal on small mammal populations in southern New Mexico, USA. Journal of Arid Environments 66:76-86.

Medin, D.E., and W.P. Clary. 1989. Small mammal populations in a grazed and ungrazed riparian habitat in Nevada. Research Paper INT-413, USDA Forest Service, Intermountain Research Station, Ogden, UT.

Meehl, G.A., T.F. Stocker, W.D. Collins, P. Friedlingstein, T. Gaye, J.M. Gregory, A. Kitoh, R. Knutti, J.M. Murphy, A. NodA, ET AL. 2007. Global climate projections. Pages 747-846 in S. Solomon et al., editors, IPCC, 2007: Climate Change 2007: the physical science basis. Contribution of Working Group I to the Fourth Assessment Report of the Intergovernmental Panel on Climate Change. Cambridge University Press, Cambridge, United Kingdom.

Miller, R.F., R.J. Tausch, E.D. McArthur, D.D. Johnson, S.C. Sanderson, and C. Stewart. 2008. Age structure and expansion of piñon-juniper woodlands: a regional perspective in the Intermountain West. Research Paper RMRS-RP-69, USDA Forest Service, Rocky Mountain Research Station, Fort Collins, CO.

MilleR, R.F., AND P.E. Wigand. 1994. Holocene changes in semi-arid pinyon-juniper woodlands: responses to climate, fire and human activities in the US Great Basin. BioScience 44:465-474.

Miller-Rushing, A.J., And R.B. Primack. 2008. Global warming and flowering times in Thoreau's Concord: a community perspective. Ecology 89:332-341.

Moritz, C., J.L. Patton, C.J. Conroy, J.L. Parra, G.C. WhITE, AND S.R. BEISSINGER. 2008. Impact of a century of climate change on small-mammal communities in Yosemite National Park, USA. Science 322 261-264.

Noss, F.R., E.T. Laroe, and J.M. SCOtT. 1995. Endangered ecosystems of the United States: a preliminary assessment of loss and degradation. Biological Report 28, USDI National Biological Service, Washington, DC.

Parker, J.D., D.E. Burkepile, and M.E. Hay. 2006. Opposing effects of native and exotic herbivores on plant invasions. Science 311:1459-1461.

Parmesan, C., N. Ryrholm, C. Stefanescu, J.K. Hill, C.D. Thomas, H. Descimon, B. Huntley, L. Kaila, J. Kullberg, T. Tammaru, et al. 1999. Poleward shifts in geographical ranges of butterfly species associated with regional warming. Nature 399:579-583.
Pieper, R.D. 1968. Comparison of vegetation on grazed and ungrazed pinyon-juniper grassland sites in south central New Mexico. Journal of Range Management 21:51-53.

Pyke, C.R., AND J. MarTy. 2005. Cattle grazing mediates climate change impacts on ephemeral wetlands. Conservation Biology 19:1619-1625.

RaLPHS, M.H. 2002. Ecological relationships between poisonous plants and rangeland condition: a review. Journal of Range Management 55:285-290.

Rickart, E.A., R.J. Rowe, S.L. Robson, L.F. Alexander, AND D.S. Rogers. 2011. Shrews of the Ruby Mountains, northeastern Nevada. Southwestern Naturalist 56:95-102.

Rogers, G.F. 1982. Then and now: a photographic history of vegetation change in the central Great Basin Desert. University of Utah Press, Salt Lake City, UT.

Rooney, T.P., S.M. Wiegmann, D.A. Roger, and D.M. WALLER. 2004. Biotic impoverishment and homogenization in unfragmented forest understory communities. Conservation Biology 18:787-798.

Rosenstock, S.S. 1996. Shrub-grassland small mammal and vegetation responses to rest from grazing. Journal of Range Management 49:199-203.

Rowe, R.J. 2007. Legacies of land use and recent climate change: the small mammal fauna in the mountains of Utah. American Naturalist 170:242-257.

Rowe, R.J., J.A. Finarelli, and E.A. Rickart. 2010. Range dynamics of small mammals along an elevational gradient over an 80-year interval. Global Change Biology 16:2930-2973.

Rowe, R.J., R.C. Terry, and E.A. RicKart. 2011. Environmental change and declining resource availability for small-mammal communities in the Great Basin. Ecology 92:1366-1375.

SARR, D.A. 2002. Riparian livestock exclosure research in the western United States: a critique and some recommendations. Environmental Management 30: $516-526$.

Schulz, T.T., AND W.C. LeININGER. 1991. Nongame wildlife communities in grazed and ungrazed montane riparian habitat. Great Basin Naturalist 51:286-292.

Swetnam, T.W., C.D. Allen, and J.L. Betancourt. 1999. Applied historical ecology: using the past to manage for the future. Ecological Applications 9:1189-1206.

Tingley, M.W., W.B. Monahan, S.R. Beissinger, and C. MORITZ. 2009. Birds track their Grinnellian niche through a century of climate change. Proceedings of the National Academy of Sciences 106 (Supplement 2):19637-19643.

[USDA-NRCS] United States Department of Agriculture-Natural Resource Conservation SerVICE. 2009. The PLANTS Database. National Plant Data Center, Baton Rouge, LA. Available from: http://plants.usda.gov/

[USDA-FS] United States Department of AgriculTURE-Forest SERvice. 2013. Humboldt-Toiyabe National Forest. Geospatial data [online]. Available from: http://www.fs.usda.gov/main/htnf/landmanage ment/gis

Valone, T.J., AND P. SAUTER. 2004. Effects of long-term cattle exclosure on vegetation and rodents at a desertified arid grassland site. Journal of Arid Environments 61:161-170.

Van Auken, O.W. 2000. Shrub invasions of North American semi-arid grasslands. Annual Review of Ecology and Systematics 31:197-215. 
VAVRA, M., W.A. LaYCOCK, AND R.D. Pieper, EDITORS. 1994 Ecological implications of livestock herbivory in the west. Society for Range Management, Denver, CO.

Whitson, T.D., L. Burrill, S. Dewey, D. Cudney, B. Nelson, R. Lee, and R. Parker. 1992. Weeds of the West. Western Society of Weed Science, University of Wyoming, Laramie, WY.
YounG, J.A., And C.D. Clements. 2006. Nevada rangelands. Rangelands 28:10-15.

Received 21 March 2013 Accepted 29 September 2013 
APPENDIX. Occurrence and functional groups of plants on grazed and ungrazed habitat at Ruby Valley Forest Service Station, Nevada.

\begin{tabular}{|c|c|c|c|c|c|c|c|}
\hline \multirow[b]{2}{*}{ Taxon } & \multicolumn{2}{|c|}{ Occurrence } & \multicolumn{5}{|c|}{ Groups } \\
\hline & Grazed & Ungrazed & Nonnative & Mesic & Xeric & Forage & Toxic \\
\hline \multicolumn{8}{|l|}{ Grasses/rushes } \\
\hline Juncus confusus & & $\mathrm{X}$ & & $\mathrm{X}$ & & $\mathrm{X}$ & \\
\hline Agrostis stolonifera & $\mathrm{X}$ & & & $\mathrm{X}$ & & $\mathrm{X}$ & \\
\hline Bromus japonicus & & $\mathrm{X}$ & $\mathrm{X}$ & $\mathrm{X}$ & & & \\
\hline Elymus cinereus & & $\mathrm{X}$ & & & & $\mathrm{X}$ & \\
\hline Elymus glaucus & & $\mathrm{X}$ & & & $\mathrm{X}$ & $\mathrm{X}$ & \\
\hline Festuca sp. & & $\mathrm{X}$ & & $\mathrm{X}$ & & $\mathrm{X}$ & \\
\hline Phleum sp. & & $\mathrm{X}$ & & $\mathrm{X}$ & & $\mathrm{X}$ & \\
\hline Poa bulbosa & $\mathrm{X}$ & & $\mathrm{X}$ & $\mathrm{X}$ & & $\mathrm{X}$ & \\
\hline Poa compressa & & $\mathrm{X}$ & & $\mathrm{X}$ & & $\mathrm{X}$ & \\
\hline Muhlenbergia sp. & & $\mathrm{X}$ & & $\mathrm{X}$ & & $\mathrm{X}$ & \\
\hline \multicolumn{8}{|l|}{ Forbs } \\
\hline Allium sp. & $\mathrm{X}$ & $\mathrm{X}$ & & & & & \\
\hline Antenaria sp. & $\mathrm{X}$ & & & & & & \\
\hline Aquilegia formosa & & $\mathrm{X}$ & & & & $\mathrm{X}$ & \\
\hline Artemisia ludoviciana & $\mathrm{X}$ & $\mathrm{X}$ & & & $\mathrm{X}$ & & \\
\hline Astragalus sp. & $\mathrm{X}$ & & & & $\mathrm{X}$ & $\mathrm{X}$ & $\mathrm{X}$ \\
\hline Balsamorhiza sp. & $\mathrm{X}$ & $X$ & & & $\mathrm{X}$ & $\mathrm{X}$ & \\
\hline Camelina sp. & $\mathrm{X}$ & & & & $\mathrm{X}$ & & \\
\hline Cirsium arvense & & $\mathrm{X}$ & $\mathrm{X}$ & & $\mathrm{X}$ & & \\
\hline Collomia linearis & $\mathrm{X}$ & $\mathrm{X}$ & & & & & \\
\hline Comandra umbellata & & $\mathrm{X}$ & & & $\mathrm{X}$ & & \\
\hline Cryptantha sp. & & $\mathrm{X}$ & & & $\mathrm{X}$ & & \\
\hline Epilobium sp. & $\mathrm{X}$ & $\mathrm{X}$ & & $\mathrm{X}$ & & & \\
\hline Ericameria sp. & & $\mathrm{X}$ & & & $\mathrm{X}$ & & \\
\hline Galium sp. & & $\mathrm{X}$ & & $\mathrm{X}$ & & & \\
\hline Hackelia sp. & & $\mathrm{X}$ & & $\mathrm{X}$ & & & \\
\hline Iva axillaris & & $\mathrm{X}$ & & & $\mathrm{X}$ & & \\
\hline Lithospermum ruderale & & $\mathrm{X}$ & & & $\mathrm{X}$ & & \\
\hline Lupinus sp. & $\mathrm{X}$ & $\mathrm{X}$ & & $\mathrm{X}$ & & & $\mathrm{X}$ \\
\hline Madia sp. & $\mathrm{X}$ & $\mathrm{X}$ & $\mathrm{X}$ & $\mathrm{X}$ & & & \\
\hline Navarretia intertexta & $\mathrm{X}$ & & & $\mathrm{X}$ & & & \\
\hline Paeonia brownii & & $\mathrm{X}$ & & $\mathrm{X}$ & & & \\
\hline Penstemon rydbergii & & $\mathrm{X}$ & & $\mathrm{X}$ & & & \\
\hline Penstemon sp. & & $\mathrm{X}$ & & $\mathrm{X}$ & & & \\
\hline Phacelia hastata & & $\mathrm{X}$ & & & $\mathrm{X}$ & $\mathrm{X}$ & \\
\hline Rumex crispus & $\mathrm{X}$ & & $\mathrm{X}$ & $\mathrm{X}$ & & & \\
\hline Senecio sp. & & $\mathrm{X}$ & & & $\mathrm{X}$ & $\mathrm{X}$ & $\mathrm{X}$ \\
\hline Sidalcea sp. & & $\mathrm{X}$ & & $\mathrm{X}$ & & & \\
\hline Toxicoscordion sp. & & $\mathrm{X}$ & & $\mathrm{X}$ & & $\mathrm{X}$ & $\mathrm{X}$ \\
\hline Trifolium sp. & $\mathrm{X}$ & $\mathrm{X}$ & & $\mathrm{X}$ & & $\mathrm{X}$ & \\
\hline Turritus glabra & & $\mathrm{X}$ & & $\mathrm{X}$ & & & \\
\hline Verbascum sp. & & $\mathrm{X}$ & & & $\mathrm{X}$ & & \\
\hline \multicolumn{8}{|l|}{ Woody plants } \\
\hline Amelanchier utahensis & $\mathrm{X}$ & $\mathrm{X}$ & & & $\mathrm{X}$ & $\mathrm{X}$ & \\
\hline Apocynum sp. & & $\mathrm{X}$ & & & $\mathrm{X}$ & $\mathrm{X}$ & $\mathrm{X}$ \\
\hline Artemisia tridentata & $\mathrm{X}$ & $\mathrm{X}$ & & & $\mathrm{X}$ & & \\
\hline Chrysothamnus viscidiflorus & $\mathrm{X}$ & $\mathrm{X}$ & & & $\mathrm{X}$ & & \\
\hline Dasiphora fruiticosa & & $\mathrm{X}$ & & $\mathrm{X}$ & & & \\
\hline Mahonia repens & $\mathrm{X}$ & & & & $\mathrm{X}$ & $\mathrm{X}$ & $\mathrm{X}$ \\
\hline Populus tremuloides & & $\mathrm{X}$ & & $\mathrm{X}$ & & $\mathrm{X}$ & \\
\hline Prunus virginiana & & $\mathrm{X}$ & & $\mathrm{X}$ & & $\mathrm{X}$ & $\mathrm{X}$ \\
\hline Purshia tridentata & $\mathrm{X}$ & & & & $\mathrm{X}$ & $\mathrm{X}$ & \\
\hline Rosa woodsii & $\mathrm{X}$ & & & & & $\mathrm{X}$ & \\
\hline Symphoricarpos oreophilus & $\mathrm{X}$ & $\mathrm{X}$ & & & $\mathrm{X}$ & $\mathrm{X}$ & \\
\hline
\end{tabular}

